\title{
Analisis Kesalahan Siswa Kelas VIII dalam Menyelesaikan Soal Cerita Terkait Teorema Pythagoras
}

\author{
Nur Hasan ${ }^{1}$, Subanji $^{1}$, Sukorianto $^{1}$ \\ ${ }^{1}$ Pendidikan Matematika-Universitas Negeri Malang
}

\begin{tabular}{l}
\hline \hline INFO ARTIKEL \\
\hline Riwayat Artikel: \\
Diterima: 04-03-2019 \\
Disetujui: 18-04-2019 \\
\hline
\end{tabular}

\section{Kata kunci:}

error analysis;

the Pythagorean theorem;

middle school student;

analisis kesalahan;

teorema pythagoras;

siswa SMP

\author{
Alamat Korespondensi: \\ Nur Hasan \\ Pendidikan Matematika \\ Universitas Negeri Malang \\ Jalan Semarang 5 Malang \\ E-mail: hnur88321@gmail.com
}

\begin{abstract}
ABSTRAK
Abstract: This research was aimed to describing the mistakes made by the eighth grade students of SMPN 2 Tiris in Probolinggo district in solving the story problems related to the Pythagorean Theorem. Three subjects were selected to solve the story problem of the Pythagorean Theorem then interviewed. The analysis used was based on conceptual error, procedural and calculation. The results showed that in the conceptual stage the subject made a mistake in drawing a right triangle and determining the sloping side. Procedural errors are made, namely the subject makes a withdrawal of the root in the right segment even though in the left side is still a square. While at the calculation stage the subject made a mistake in determining the results of the square root and the difference so that it was wrong in the final result.

Abstrak: Penelitian ini bertujuan untuk mendeskripsikan kesalahan yang dilakukan siswa kelas VIII SMPN 2 Tiris Kabupaten Probolinggo dalam menyelesaikan soal cerita terkait Teorema Pythagoras. Tiga subjek dipilih untuk menyelesaikan soal cerita Teorema Pythagoras kemudian diwawancara. Analisis yang digunakan berdasarkan kesalahan konseptual, prosedural, dan komputasi. Hasil penelitian menunjukkan pada tahap konseptual subjek melakukan kesalahan dalam menggambar segitiga siku-siku dan menentukan sisi miringnya. Kesalahan prosedural yang dilakukan yaitu subjek melakukan penarikan akar pada ruas kanan padahal di ruas kiri masih bentuk kuadrat. Pada tahap penghitungan subjek melakukan kesalahan dalam menentukan hasil akar kuadrat dan selisih sehingga salah dalam hasil akhir.
\end{abstract}

Dalam kehidupan manusia selalu ada yang namanya masalah sehingga kita selalu dituntut untuk mampu memecahkan masalah dengan sebaik-baiknya. Polya (1957) menyatakan bahwa aktivitas utama manusia selalu berhubungan dengan pemecahan masalah, bahkan sebagian besar pikiran sadar manusia digunakan untuk menyelesaikan masalah. (Scheiter, dkk, 2010) menyatakan bahwa dalam konteks pembelajaran matematika, masalah yang berhubungan dengan kehidupan sehari-hari biasanya disajikan secara verbal atau disebut juga sebagai soal cerita. Masalah kontekstual dipaparkan dalam bentuk soal cerita, sehingga soal cerita merupakan masalah paling umum yang dapat ditemui di setiap tingkatan sekolah mulai dari tingkat TK hingga Universitas (Jonassen, 2003). Chapman (2006) menyatakan bahwa soal cerita dapat menjadi sarana untuk menerapkan pembelajaran matematika terhadap konteks kehidupan sehari-hari, dengan memanfaatkan soal cerita konsep-konsep abstrak matematika lebih mudah dipahami. Boaler (1993) menyatakan bahwa keadaan yang sesuai dengan kehidupan nyata pada soal cerita dapat menarik minat siswa dalam mempelajari matematika. Namun, terkadang dalam kenyataan terjadi bahwa soal cerita menjadi masalah bagi siswa. Jupri \& Drijvers (2016) menyatakan bahwa dalam menyelesaikan masalah soal cerita menjadi kendala utama belajar aljabar bagi siswa sekolah menengah di seluruh dunia. TIMSS menyatakan bahwa di Indonesia siswa kesulitan dalam menyelesaikan soal cerita sehingga dalam menyelesaikan permasalahan berbentuk soal cerita banyak siswa yang melakukan kesalahan.

Kesalahan merupakan perbuatan yang salah, kekeliruan atau tidak sengaja diperbuat (Purwadarminta, 1985). Kesalahan yang sering terjadi dalam menyelesaikan soal matematika adalah kesalahan prosedur yang kurang tepat sehingga mengakibatkan siswa kurang tepat dalam jawabannya (Sunardi, 1995). Dengan memberikan tes atau soal tentang materi yang sudah dipelajari dapat mengetahui kemampuan menyelesaikan soal matematika siswa. Dengan adanya kesalahan siswa dalam menyelesaikan soal maka dapat menjadi salah satu cara untuk mengetahui sejauh mana siswa itu memahami materi yang telah diajarkan. Dengan adanya kesalahan perlu diidentifikasi faktor-faktornya dan kemudian dicari solusi penyelesaian yang memengaruhi kesalahan tersebut. Legutko (2008) menyatakan bahwa kesalahan terjadi ketika (1) seseorang memilih hal yang salah menjadi benar, (2) ketika hasil tidak sesuai dengan harapan, (3) ketika tindakan yang dilakukan tidak sesuai dengan 
prosedur. Kesalahan dapat terjadi ketika siswa menyelesaikan soal atau tugas di sekolah. Adapun untuk mengetahui bagaimana kesalahan terjadi dilakukan analisis kesalahan. Menurut Brown \& Skow (2016) analisis kesalahan merupakan penilaian diagnostik yang dapat digunakan guru untuk menentukan jenis-jenis kesalahan siswa serta penyebabnya.

Dalam penelitian ini analisis kesalahan siswa yang dipakai terbagi dalam beberapa tahap, yaitu (1) kesalahan konseptual, (2) kesalahan prosedural, dan (3) kesalahan komputasi. Kesalahan prosedural terjadi ketika siswa melakukan kesalahan dalam tahapan penyelesaian. Kesalahan komputasi terjadi apabila siswa melakukan kesalahan dalam menentukan hasil dalam perhitungan. Adapun untuk menyelidiki terjadinya kesalahan tersebut diperlukan analisis terhadap beberapa sumber, misalnya hasil jawaban siswa dan wawancara.

\section{METODE}

Jenis penelitian ini adalah penelitian kualitatif deskriptif yang berupa studi kasus. Instrumen yang digunakan pada penelitian ini yaitu lembar tes soal cerita Teorema Pythagoras dan pedoman wawancara. Siswa yang diteliti diperoleh seleksi dari sepuluh siswa kelas VIII SMPN 2 Tiris Kabupaten Probolinggo yang melakukan tiga kesalahan yaitu kesalahan konseptual, kesalahan prosedural dan kesalahan komputasi melalui tes bersama. Pada instrumen siswa diberikan satu butir soal berbentuk cerita. Tugas siswa adalah menyelesaikan soal tersebut dengan beserta cara penyelesaian tetapi sebelumnya di transformasi ke dalam bentuk gambar.

Setelah siswa selesai mengerjakan, hasil jawaban siswa dianalisis dan diwawancara untuk mengonfirmasi hasil pekerjaannya. Di dalam wawancara, ada tiga tahapan, yaitu (1) siswa diminta membaca dan memahami kembali isi dan permintaan dari soal; (2) siswa dituntut untuk mentransformasi soal ke dalam bentuk gambar yaitu segitiga siku-siku; (3) siswa agar cermat dalam menghitung. Sehingga siswa yang melakukan kesalahan dalam penyelesaian masalah dan terdapat indikasi menggunakan pemodelan matematis dijadikan subjek penelitian. Data penelitian berupa hasil pekerjaan siswa dan transkrip wawancara. Soal cerita Teorema Pythagoras yang digunakan sebagai instrumen yaitu "Sebuah kapal nelayan bertolak dari pelabuhan untuk menangkap ikan tuna yang biasanya berkumpul di suatu titik dilepas pantai. Agar bisa menangkap ikan tuna lebih banyak, kapal nelayan itu tidak langsung menuju ke tempat tersebut, tetapi berlayar melewati jalur yang baru yaitu $12 \mathrm{~km}$ ke barat kemudian $35 \mathrm{~km}$ ke selatan. Berapa jarak tempuh pergi pulang (berangkat menggunakan jalur baru dan pulangnya melewati jalur lama ?" Teknik analisis data dilakukan dengan cara (1) mendeskripsikan hasil pekerjaan subjek secara naratif, (2) menggambarkan struktur jawaban subjek, dan (3) melakukan analisis kesalahan siswa berdasarkan analisis kesalahan kastolan.

Tabel 1. Indikator Penelitian

\begin{tabular}{lll}
\hline Tipe Kesalahan & & Indikator \\
\hline Kesalahan Konseptual & a) Salah dalam mentransformasi soal cerita ke dalam bentuk geometri (segitiga siku-siku) \\
& b) Salah dalam menentukan sisi miring suatu segitiga siku-siku \\
& c) Salah dalam menentukan rumus atau teorema yang tepat \\
& d) Tidak menuliskan rumus atau teorema untuk menjawab suatu masalah \\
\hline Kesalahan Prosedural & a) Tidak menggambar permasalahan ke dalam bentuk geometri (segitiga siku-siku) terlebih dahulu \\
& b) Tidak menuliskan informasi yang diketahui dengan lengkap \\
& c) Proses penarikan akar-akar di ruas kanan, tetapi di ruas kiri masih dalam bentuk kuadrat \\
\hline Kesalahan Komputasi & a) Salah menentukan hasil operasi. \\
\hline
\end{tabular}

\section{HASIL}

Sepuluh siswa yang akan diberikan tes, terlebih dahulu diberi pengetahuan tentang materi Teorema Pythagoras. Setelah itu peneliti memberikan naskah soal yang berupa sebuah butir soal terkait teorema Pythagoras yang berbentuk soal cerita. Dari 10 siswa yang mendapatkan soal tes diperoleh hasil yaitu, empat siswa melakukan kesalahan konseptual, tiga siswa melakukan kesalahan prosedural dan tiga siswa mengalami kesalahan komputasi. Ada satu siswa melakukan kesalahan konsetual dan kesalahan prosedural saja, satu siswa melakukan kesalahan prosedural dan kesalahan komputasi saja serta dua siswa melakukan kesalahan konseptual dan kesalahan komputasi saja. Terdapat tiga siswa, yaitu MSR, BS, dan AR yang mengalami kesalahan konseptual, prosedural dan kesalahan komputasi sehingga peneliti menjadikan ketiga siswa ini menjadi subjek.

Hasil atau uraian jawaban dari tiga subjek akan dianalisa dan akan diberikan wawancara sesuai dengan kesalahannya masing-masing. Pada penelitian ini tiga masing-masing subjek, yaitu MSR (subjek 1), BS (subjek 2), dan AR (subjek 3) akan diberikan wawancara oleh peneliti (P) dengan tujuan untuk memastikan peneliti mengenai kesalahan subjek dan kesalahan itu akan dideskripsikan. Dengan wawancara, subjek mengetahui kesalahannya dan memahami cara memperbaiki kesalahan itu. Berikut akan dipaparkan hasil jawaban tiga subjek beserta wawancaranya. 


\section{Analisis Kesalahan pada Subjek 1 (MSR)}

Subjek 1 melakukan kesalahan konseptual ketika subjek 1 mentransformasi soal cerita ke dalam bentuk gambar, yaitu ketidaktepatan arah pada gambar. Subjek 1 juga melakukan kesalahan prosedural yaitu ketika subjek 1 melakukan penarikan akar pada ruas kanan tetapi di ruas kiri masih dalam bentuk kuadrat. Pada proses penghitungan subjek 1 juga melakukan kesalahan yaitu pada saat menentukan nilai akar. Berikut hasil uraian jawaban subjek 1.

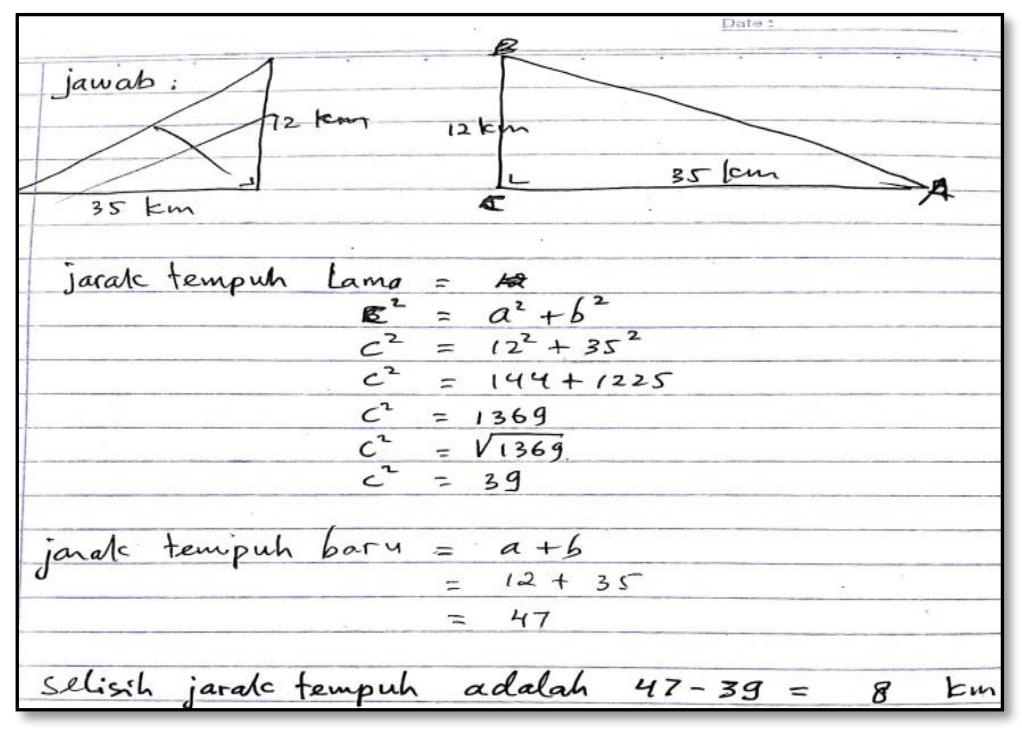

Gambar 1. Hasil Pekerjaan MSR

Pada gambar 1 terlihat subjek 1 melakukan kesalahan, untuk mengetahui dengan pasti letak kesalahan itu peneliti melakukan wawancara terhadap subjek 1 , dengan tujuan subjek 1 bisa mengetahui kesalahannya dan mampu menyelesaikan soal cerita ini dengan baik dan benar. Berikut kegiatan wawancara dengan subjek 1.

P : : Coba Anda ceritakan maksud dari soal ini apa!

MSR : Maksudnya adalah ada kapal yang berlayar melewati dua jalur, yaitu jalur lama dan jalur baru. Jalur lama yaitu jalur langsung menuju target sedangkan jalur baru yaitu jalur ke barat dulu baru berbelok ke selatan. Yang diminta soal adalah selisih jarak tempuh jalur lama dan jalur baru, begitu Pak.

P : : coba lihat hasil jawaban Anda! apakah gambar Anda sesuai dengan cerita soal?

MSR : Menurut saya sudah Pak

$\mathrm{P} \quad$ : Coba Anda ingat, pada peta itu arah utara itu kemana?

MSR : Saya kurang tau Pak

$\mathrm{P} \quad$ : Apakah Anda pernah lihat peta?

MSR : Pernah Pak

$\mathrm{P} \quad$ : Di bagian pojok peta itu biasanya terdapat arah mata angin, nah utara itu ke arah mana?

MSR : Oh ya Pak, utara itu ke atas

$\mathrm{P} \quad$ : Kalau utara ke atas berarti arah barat, timur dan selatan kemana?

MSR : Barat ke kiri, selatan ke bawah dan timur ke kanan Pak

$\mathrm{P} \quad$ : Coba Anda perbaiki gambar Anda!

MSR : Ya Pak (subjek 1menggambar kembali dengan benar)

Pada dialog ini subjek melakukan kesalahan konseptual terkait arah mata angin, sehingga gambar pada jawaban subjek 1 tidak sesuai dengan cerita soal. Peneliti melakukan wawancara sehingga subjek 1 bisa mengingat kembali tentang arah pada peta dan bisa menggambar ulang dengan baik dan benar. Untuk mengetahui kesalahan subjek 1 terkait kesalahan prosedural, peneliti melakukan wawancara sebagai berikut.

$\mathrm{P} \quad$ : Coba perhatikan uraian jawaban Anda!

MSR : Ya Pak

$\mathrm{P} \quad$ : Pada baris ke empat, dan seterusnya, di ruas kanan Anda sudah melakukan penarikan akar, sedangkan di ruas kiri masih dalam bentuk kuadrat. Berarti hasil Anda adalah masih dalam bentuk kuadrat.

MSR : Ya Pak, oh berarti saya hapus ya Pak kuadratnya.

$\mathrm{P} \quad:$ Coba Anda pikir ulang....jika terdapat $x^{2}=9$, maka apakah $x^{2}= \pm 3$ ?

MSR : Ya Pak, seharusnya ketika saya sudah menarik akar maka ruas kiri tidak dalam bentuk kuadrat

P : Coba Anda ubah jawabannya! 
Pada dialog ini tampak terlihat jelas subjek 1 melakukan kesalahan tahapan pada penyelesaian yaitu pada saat ruas kanan sudah ditarik akar maka seharusnya ruas kiri sudah dalam bentuk pangkat satu ini adalah kesalahan prosedural. Peneliti melakukan wawancara ini sehingga subjek 1 mengetahui urutan yang benar pada saat menyelesaikan soal ini. Untuk mengetahui kesalahan komputasi pada subjek 1, peneliti melanjutkan wawancara sebagai berikut.

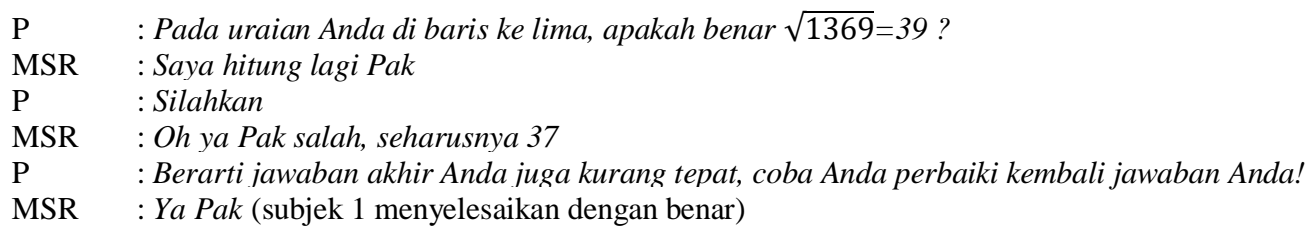

Pada dialog tersebut, subjek 1 melakukan kesalahan komputasi (penghitungan) terkait hasil penarikan akar. Subjek ceroboh dalam menentukan hasil akar kuadrat dari 1369. Setelah mengetahui kesalahannya subjek 1 mengubah jawaban dengan lebih hati-hati sehingga diperoleh jawaban yang benar. Pada kesalahan komputasi banyak siswa melakukan karena kurang hatihati dalam penghitungan.

Pada subjek 1 setelah dilakukan wawancara ditemukan beberapa kesalahan yaitu kesalahan konseptual, kesalahan prosedural dan kesalahan komputasi. Subjek 1 melakukan kesalahan konseptual yaitu ketika subjek 1 salah dalam menggambar yaitu mengenai arah mata angin dalam menggambar. Subjek menggambar arah barat ke arah bawah dan menggambar arah selatan ke arah kanan. Subjek 1 juga melakukan kesalahan prosedural pada saat subjek melakukan penarikan akar pada ruas kanan, sedangkan pada ruas kiri masih dalam bentuk kuadrat. Subjek 1 menyelesaikan sehingga hasil akhir tetap dalam bentuk kuadrat. Kesalahan yang ketiga adalah kesalahan komputasi, yaitu subjek 1 melakukan kesalahan komputasi pada saat menentukan hasil akar di ruas kanan. Dari ketiga kesalahan tersebut, peneliti melakukan wawancara sehingga subjek mengetahui kesalahannya dan memahami konsep, prosedur bahkan penghitungan yang benar. Sehingga subjek 1 menyelesaikan kembali soal dengan benar.

\section{Analisis Kesalahan pada Subjek 2 (BS)}

Subjek 2 sudah menggambar dengan benar, tetapi masih melakukan kesalahan konseptual yaitu salah dalam menentukan sisi miringnya. Sehingga subjek salah dalam mensubtitusi nilai sisi ke dalam rumus Teorema Pythagoras. Subjek 2 juga melakukan kesalahan prosedural yaitu ketika subjek 2 melakukan penarikan akar pada ruas kanan, tetapi di ruas kiri masih dalam bentuk kuadrat. Pada proses penghitungan subjek 2 juga melakukan kesalahan yaitu pada saat menentukan nilai akar. Subjek 2 menarik akar hanya dengan membagi dengan 2 atau separuhnya. Berikut hasil uraian jawaban subjek 2.

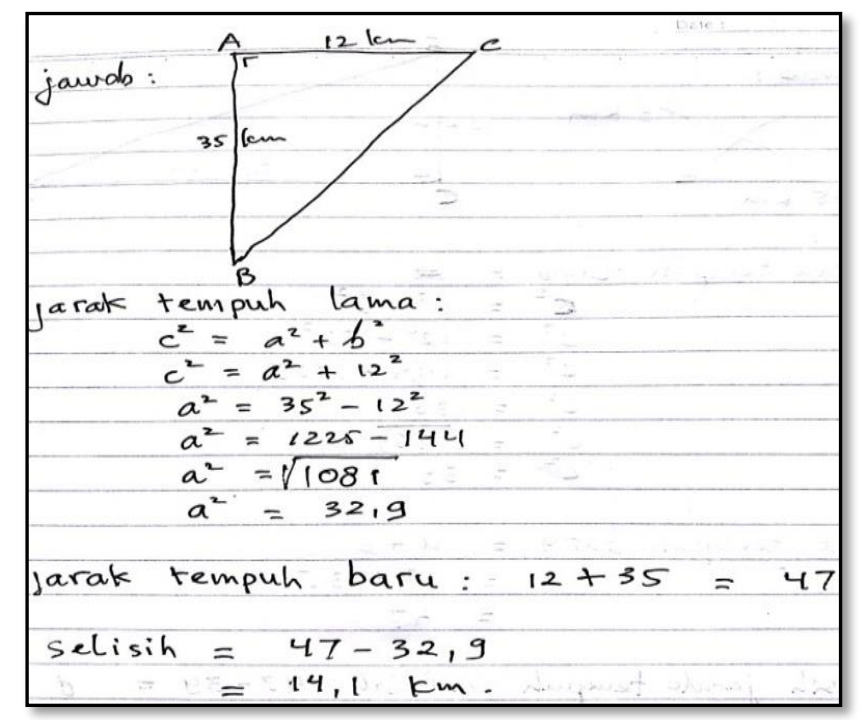

Gambar 2. Hasil Pekerjaan BS Sebelum Direvisi

Pada gambar 2 terlihat subjek 2 melakukan kesalahan, untuk mengetahui dengan pasti letak kesalahan itu peneliti melakukan wawancara terhadap subjek 2, dengan tujuan subjek 2 bisa mengetahui kesalahannya dan mampu menyelesaikan soal cerita ini dengan baik dan benar. Berikut kegiatan wawancara dengan subjek 2. 
$\mathrm{P} \quad$ : Coba Anda ceritakan maksud dari soal ini apa!

BS : Maksud dari soal ini adalah ada kapal yang berlayar melewati dua jalur yaitu jalur lama dan jalur baru. Jalur lama yaitu jalur langsung mеnuju target sedangkan jalur baru yaitu jalur ke barat dulu baru berbelok ke selatan. Yang diminta soal adalah selisih jarak tempuh jalur lama dan jalur baru, begitu Pak.

$\mathrm{P} \quad$ : Coba lihat hasil jawaban Anda! Gambar Anda sudah sesuai dengan cerita pada soal, tetapi sisi miringnya itu yang mana?

BS : Sisic Pak.

$\mathrm{P} \quad$ : Coba Anda jelaskan sisi miring itu apa!

BS : Sisi yang ada nama c Pak

$\mathrm{P} \quad$ : Kalau namanya saya tukar sisi c saya tukar dengan sisi b berarti sisi miringnya pindah gitu? Atau sisinya saya ganti dengan p, $q$ dan $r$ berrarti tidak ada sisimiringnya?

BS : : Ya Pak berarti saya salah Pak

$\mathrm{P} \quad$ : Coba perhatikan beberapa contoh segitiga berikut beserta sisi miringnya (subjek memberikan beberapa contoh segitiga siku-siku beserta sisi miringnya)

BS : Oh ya Pak

$\mathrm{P} \quad$ : Bagaimana, apakah sudah memahami tentang sisi miring?

BS $\quad$ : oh..........sisi miring itu sisi yang di depan sudut siku-siku ya Pak, saya baru tau

P : : Nah Anda sudah paham

BS : : Ya Pak terimakasih

Pada dialog ini subjek melakukan kesalahan konseptual terkait sisi miring. Subjek 2 sudah benar dalam menggambar tetapi salah dalam menentukan sisi miringnya sehingga subjek salah dalam memasukkan nilai sisinya. Kesalahan ini sangat memengaruhi penyelesaian berikutnya karena subjek akan melakukan kesalahan beruntun. Peneliti melakukan wawancara kepada subjek 2 sehingga subjek bisa memahami apa yang dimaksud sisi miring dan bisa menentukannya. Untuk mengetahui kesalahan subjek 2 terkait kesalahan prosedural, peneliti melakukan wawancara sebagai berikut.

P : : Coba perhatikan uraian jawaban Anda terkait tahapan penyelesaiannya!

BS : : Ya Pak

P $\quad$ : Pada baris ke empat,dan seterusnya, pada ruas kanan Anda sudah melakukan perubahan bentuk menjadi akar kuadrat sedangkan di ruas kiri masih dalam bentuk kuadrat dan hasil Anda masih dalam bentuk kuadrat.

MSR : Ya Pak, berarti setelah kita akar ruas kanan maka ruas kiri sudah dalam bentuk pangkat lya Pak?

$\mathrm{P} \quad$ : Nah gitu kan bisa

MSR : Ya Pak, seharusnya ketika saya sudah menarik akar maka ruas kiri tidak dalam bentuk kuadrat sampai jawaban akhir

Pada dialog ini tampak terlihat jelas subjek 2 melakukan kesalahan tahapan pada penyelesaian yaitu pada saat ruas kanan sudah ditarik akar maka seharusnya ruas kiri sudah dalam bentuk pangkat satu, ini adalah kesalahan prosedural. Peneliti melakukan wawancara ini sehingga subjek 2 mengetahui urutan yang benar pada saat menyelesaikan soal ini. Sebelum dilakukan wawancara untuk mengetahui kesalahan prosedural peneliti meminta subjek untuk mengerjakan ulang terkait jarak tempuh, sehingga diharapkan subjek tidak melakukan kesalahan yang beruntun. Berikut jawaban ulang oleh subjek 2 .

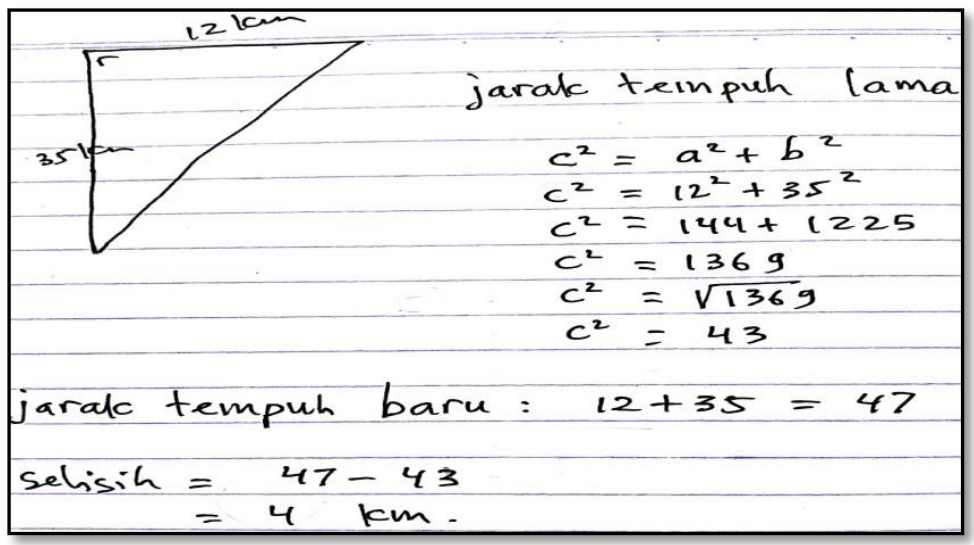

Gambar 2. Hasil Pekerjaan BS Sesudah Direvisi

Untuk mengetahui kesalahan komputasi pada subjek 2 peneliti melanjutkan wawancara sebagai berikut.

P : Pada uraian Anda di baris ke lima, apakah benar $\sqrt{1369}=43$ ?

BS : : Menurut saya benar Pak

P : Bagaimana Anda menentukan akar kuadrat? 


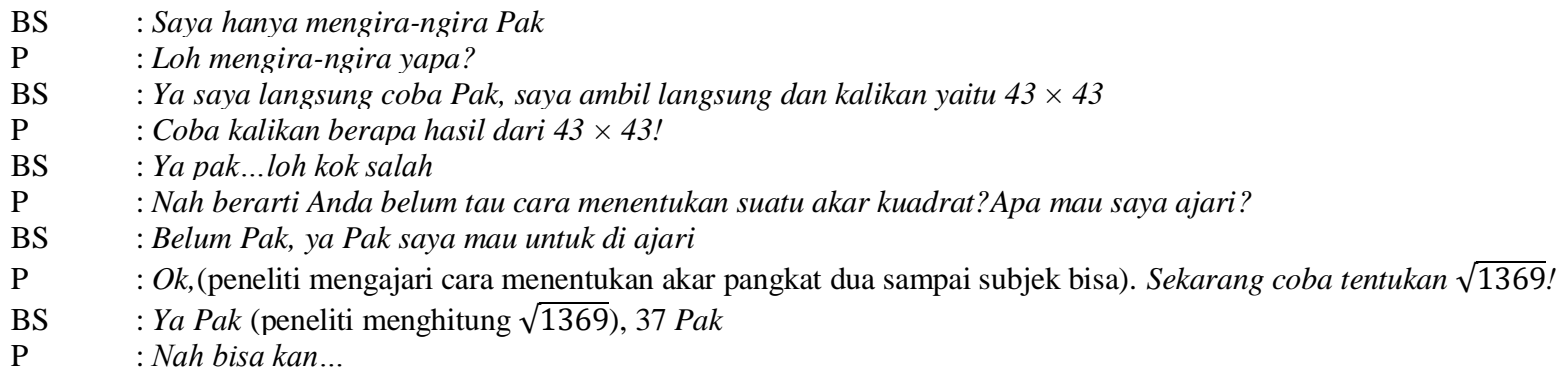

Pada dialog tersebut subjek 2 melakukan kesalahan komputasi (penghitungan) terkait hasil penarikan akar. Terrnyata subjek 2 dalam penarikan akar kuadrat dengan cara mengira-mengira. Sehingga perkiraan subjek 2 salah dan peneliti memberikan cara untuk menentukan akar kuadrat yang benar. Setelah mengetahui kesalahannya, subjek 2 mengubah jawaban dengan lebih hati-hati sehingga diperoleh jawaban yang benar. Pada kesalahan komputasi banyak siswa melakukan karena kurang hati-hati dalam penghitungan dan karena memang subjek tidak mengerti cara menentukannya.

Pada subjek 2 setelah dilakukan wawancara ditemukan beberapa kesalahan yaitu kesalahan konseptual, kesalahan prosedural dan kesalahan komputasi. Subjek 2 melakukan kesalahan konseptual yaitu ketika subjek 2 salah dalam menentukan sisi miring pada segitiga siku-siku sehingga subjek salah dalam memasukkan nilai sisinya. Subjek 2 juga melakukan kesalahan prosedural pada saat subjek melakukan penarikan akar pada ruas kanan, sedangkan pada ruas kiri masih dalam bentuk kuadrat. Subjek 2 menyelesaikan sehingga hasil akhir tetap dalam bentuk kuadrat. Kesalahan yang ketiga adalah kesalahan komputasi, yaitu subjek 2 melakukan kesalahan komputasi pada saat menentukan hasil akar. Subjek 2 hanya dengan mengira-ngira dalam menentukan hasil akar kuadrat. Pada subjek 2 kesalahan mendasar yaitu kesalahan konseptual dilakukan pada saat subjek menentukan sisi miring sehingga penyelesaian berikutnya mengalami kesalahan beruntun. Dari ketiga kesalahan tersebut peneliti melakukan wawancara sehingga subjek mengetahui kesalahannya dan memahami konsep, prosedur bahkan penghitungan yang benar. Sehingga subjek 2 menyelesaikan kembali soal dengan benar.

\section{Analisis kesalahan terhadap Subjek 3 (AR)}

Subjek 3 melakukan kesalahan konseptual ketika subjek 3 mentransformasi soal cerita ke dalam bentuk gambar, yaitu ketidaktepatan arah pada gambar. Subjek 3 juga melakukan kesalahan prosedural yaitu ketika subjek 3 melakukan penarikan akar pada ruas kanan, tetapi di ruas kiri masih dalam bentuk kuadrat. Pada proses penghitungan subjek 3 juga melakukan kesalahan yaitu pada saat menentukan selisih jarak tempuh kapal. Berikut hasil uraian jawaban subjek 3.

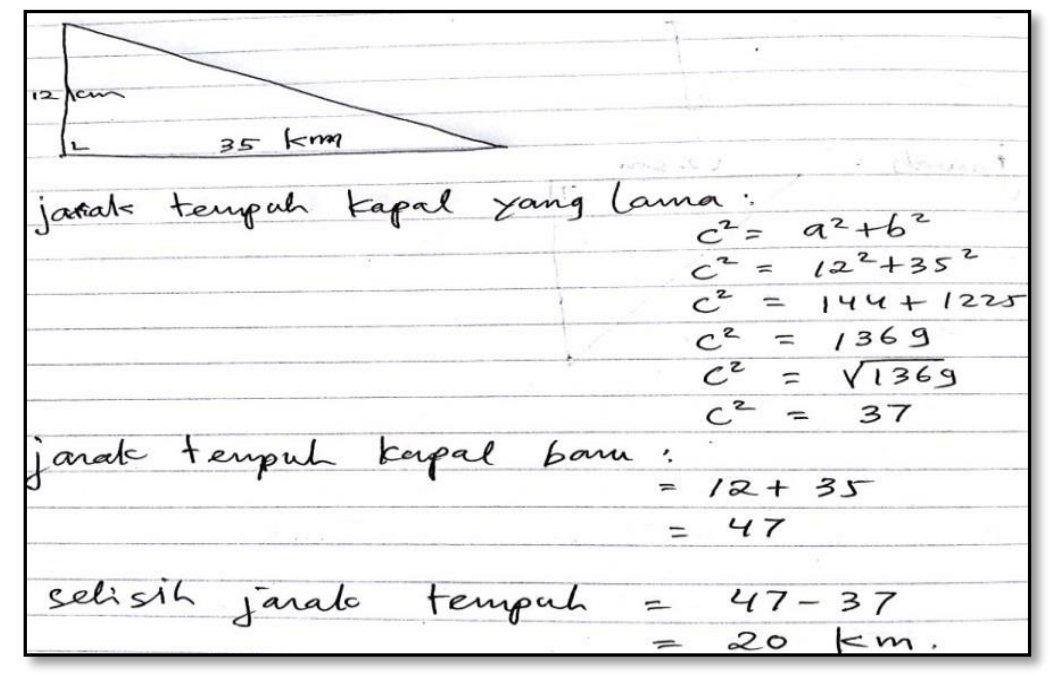

\section{Gambar 3. Hasil Pekerjaan AR}

Pada gambar 3 di atas terlihat subjek 3 melakukan kesalahan, untuk mengetahui dengan pasti letak kesalahan itu peneliti melakukan wawancara terhadap subjek 3, dengan tujuan agar subjek 3 bisa mengetahui kesalahannya dan mampu menyelesaikan soal cerita ini dengan baik dan benar. Berikut kegiatan wawancara dengan subjek 3 . 
$\mathrm{P} \quad$ : Coba Anda ceritakan maksud dari soal!

AR : Ada kapal yang berlayar melewati dua jalur yaitu jalur lama dan jalur baru. Jalur lama yaitu jalur langsung menuju target sedangkan jalur baru yaitu jalur ke barat dulu baru berbelok ke selatan. Yang diminta soal adalah selisih jarak tempuh jalur lama dan jalur baru, begitu Pak.

$\mathrm{P} \quad$ : Apakah gambar Anda sesuai dengan cerita soal?

AR : : Saya menggambar pokoknya segitiga siku-siku Pak

$\mathrm{P} \quad$ : Apakah Anda belum memahami arah pada peta, arah utara itu kemana?

AR : : Saya kurang tau Pak

$\mathrm{P} \quad$ : Apakah Anda pernah lihat peta?

AR : Pernah Pak

$\mathrm{P} \quad$ : Di bagian pojok peta itu biasanya terdapat arah mata angin, nah utara itu kea rah mana?

AR : Oh ya Pak, utara itu ke atas

$\mathrm{P} \quad$ : Kalau utara ke atas berarti arah barat, timur dan selatan kemana?

AR : Barat ke kiri, selatan ke bawah dan timur ke kanan Pak

$\mathrm{P} \quad$ : Coba Anda perbaiki gambar Anda!

AR : Ya Pak (subjek menggambar ulang segitiga siku-siku sesuai soal dengan benar)

Pada dialog ini subjek melakukan kesalahan konseptual terkait arah mata angin sehingga gambar pada jawaban subjek 3 tidak sesuai dengan cerita soal. Peneliti melakukan wawancara, sehingga subjek 3 bisa mengingat kembali tentang arah pada peta dan bisa menggambar ulang dengan baik dan benar. Untuk mengetahui kesalahan subjek 3 terkait kesalahan prosedural, peneliti melakukan wawancara sebagai berikut.

P : Coba perhatikan uraian jawaban Anda!

AR : : Ya Pak

$\mathrm{P} \quad$ : Pada baris ke empat,dan seterusnya, di ruas kanan Anda sudah melakukan penarikan akar sedangkan di ruas kiri masih dalam bentuk kuadrat. Tetapi hasil akhir Anda langsung dalam pangkat satu.

AR : : Ya Pak, jawaban saya salah Pak?

$\mathrm{P} \quad$ : Coba Anda pikir ulang....jika terdapat

$x^{2}=16$, maka apakah

$x^{2}= \pm 3$ atau $x= \pm 3$, apakah $x$ masih dalam pangkat 2 atau sudah dalam pangkat 1 ?

AR : : Ya Pak, seharusnya ketika saya sudah menarik akar maka ruas kiri tidak dalam bentuk kuadrat

$\mathrm{P} \quad$ : Ok, coba Anda rubah jawabannya!

AR $\quad:$ YaPak.

Pada dialog ini tampak terlihat jelas, subjek 3 melakukan kesalahan tahapan pada penyelesaian yaitu pada saat ruas kanan sudah ditarik akar maka seharusnya ruas kiri sudah dalam bentuk pangkat satu, ini adalah kesalahan prosedural. Peneliti melakukan wawancara ini sehingga subjek 3 mengetahui urutan yang benar pada saat menyelesaikan soal ini. Untuk mengetahui kesalahan komputasi pada subjek 3 peneliti melanjutkan wawancara sebagai berikut.

$\mathrm{P}$

: Anda sudah benar dalam menentukan jarak tempuh jalur lama dan jarak tempuh jalur baru. Tetapi coba Anda koreksi kembali saat Anda menghitung selisihnya!

AR $\quad$ : Ya Pak (subjek menghitung kembali hasil akhir yaitu selisihnya). Loh ya saya salah Pak

$\mathrm{P} \quad$ : Coba Anda jawab lagi soal itu dengan sempurna!

AR : Siap Pak

Pada dialog tersebut subjek 3 melakukan kesalahan komputasi (penghitungan) terkait hasil pengurangan. Setelah mengetahui kesalahannya subjek 3 mengubah jawaban dengan lebih hati-hati sehingga diperoleh jawaban yang benar. Pada kesalahan komputasi banyak siswa melakukan karena kurang hati-hati (ceroboh) dalam penghitungan.

Pada subjek 3 setelah dilakukan wawancara ditemukan beberapa kesalahan yaitu kesalahan konseptual, kesalahan prosedural dan kesalahan komputasi. Subjek 3 melakukan kesalahan konseptual yaitu ketika subjek 3 salah dalam menggambar yaitu mengenai arah mata angin. Subjek menggambar arah barat ke arah bawah dan menggambar arah selatan ke arah kanan. Subjek 3 juga melakukan kesalahan prosedural pada saat subjek melakukan penarikan akar pada ruas kanan, sedangkan pada ruas kiri masih dalam bentuk kuadrat. Subjek 3 menyelesaikan tetapi hasil akhir secara langsung berubah dalam bentuk pangkat satu. Kesalahan yang ketiga adalah kesalahan komputasi, yaitu subjek 3 melakukan kesalahan komputasi pada saat menentukan selisih. Subjek ceroboh dalam menghitung yaitu mengurangi jarak tempuh kapal. Dari ketiga kesalahan tersebut, peneliti melakukan wawancara sehingga subjek mengetahui kesalahannya dan memahami konsep, prosedur bahkan penghitungan yang benar sehingga subjek 3 menyelesaikan kembali soal dengan benar. 


\section{PEMBAHASAN}

Berdasarkan paparan data dan temuan oleh peneliti, terdapat beberapa klasifikasi kesalahan yang muncul ketika subjek menyelesaikan soal terkait Teorema Pythagoras. Klasifikasi kesalahan ini dianalisis pada masing-masing subjek. Analisis kesalahan yang dilakukan terhadap hasil jawaban naskah soal tes menunjukkan bahwa ketiga subjek melakukan kesalahan dalam menentukan jawaban salah atau benar dan kesalahan dalam memberi alasan, kesalahan ketiga subjek bervariasi dalam menyelesaikan soal Pythagoras. Wawancara yang dilakukan oleh peneliti kepada masing-masing subjek bervariasi tergantung pada kesalahan dan respons mereka ketika wawancara.

Pemahaman konsep dan prosedur yang digunakan oleh siswa terkait penyelesaian materi itu bervariasi sehingga setiap siswa melakukan kesalahan yang berbeda-beda juga (Roselizawati, 2014). Kesalahan yang ditemukan pada penelitian ini adalah kesalahan konseptual, kesalahan prosedural, dan kesalahan komputasi. Berikut paparan data terkait kesalahan 10 siswa sehingga peneliti mengambil tiga siswa sebagai subjek.

Tabel 2. Hasil Analisa Kesalahan Siswa

\begin{tabular}{cccc}
\hline Subjek & Kesalahan Konseptual & Kesalahan prosedural & Kesalahan komputasi \\
\hline S1 & $\sqrt{ }$ & $\sqrt{ }$ & $\sqrt{ }$ \\
\hline S2 & $\sqrt{ }$ & $\sqrt{ }$ & \\
\hline S3 & $\sqrt{ }$ & $\sqrt{ }$ & \\
\hline S4 & $\sqrt{ }$ & $\sqrt{ }$ & \\
\hline S5 & & & $\sqrt{ }$ \\
\hline S6 & $\sqrt{ }$ & & $\sqrt{ }$ \\
\hline S7 & $\sqrt{ }$ & $\sqrt{ }$ \\
\hline S8 & $\sqrt{ }$ & & 5 \\
\hline S9 & $\sqrt{ }$ & 5 & \\
\hline Banyak & $\sqrt{ }$ & 5 & 5 \\
\hline
\end{tabular}

Berdasarkan tabel 2, siswa paling banyak melakukan kesalahan konseptual. Basuki (2005) menyatakan bahwa kesalahan siswa dalam menyelesaikan soal-soal adalah kesalahan konsep dan kesalahan kecerobohan, dengan kesalahan konsep menjadi kesalahan yang dominan. Sari (2013) menyatakan bahwa siswa salah dalam memahami konsep segitiga siku-siku dan konsep teorema Pythagoras, disebabkan kurang cermat dalam membaca, tidak cermat dalam berpikir, lemah dalam menganalisis suatu masalah dan tidak mampu menerjemahkan masalah kontekstual ke dalam bentuk gambar. Siswa juga mempunyai kelemahan dalam materi prasyarat dalam hal ini yaitu aljabar dan geometri dan juga materi yang dipelajari saat ini yaitu Teorema Pythagoras. Subjek juga lemah dalam mencermati soal cerita yang kontekstual, salah dalam melakukan penghitungan dan kurang teliti (Malau, 1996). Pada penelitian ini peneliti menekankan kesalahan ke dalam tiga kriteria, yaitu kesalahan konseptual, kesalahan prosedural, dan kesalahan komputasi.

\section{Kesalahan Konseptual}

Pada penelitian ini, semua subjek melakukan kesalahan konseptual, kesalahan prosedural dan kesalahan komputasi. Akan tetapi, bentuk dari masing-masing kesalahan berbeda sehingga peneliti melakukan wawancara dan scaffolding yang berbeda pula. Selanjutnya, peneliti ingin memaparkan bentuk-bentuk kesalahan (konseptual, prosedural dan komputasi) pada setiap subjek serta scaffolding yang dilakukan.

Subjek S1 melakukan kesalahan konseptual ketika membuat gambar segitiga siku-siku tentang permasalahan pada soal. Subjek melakukan kesalahan konseptual yaitu subjek tidak memahami konsep arah mata angin, sehingga subjek menggambar terbalik. Subjek menggambar arah barat ke arah bawah dan menggambar arah selatan ke arah kanan. Sehingga peneliti melakukan wawancara untuk memahami subjek tentang arah pada mata angin agar bisa menggambar segitiga siku-siku dengan benar. Subjek 2 sudah menggambar segitiga siku-siku dengan benar terkait arahnya. Pada teorema Pythagoras terkait dengan rumus $c^{2}=a^{2}+b^{2}$, subjek memahami dalam segitiga siku-siku sisi c adalah selalu sebagai sisi miring sehingga teorema Pythagoras selalu dalam bentuk $c^{2}=a^{2}+b^{2}$ bernilai benar. Peneliti memberikan wawancara terhadap Subjek S2 berupa pertanyaan-pertanyaan untuk menguatkan konsep sisi miring pada segitiga siku-siku. Sehingga subjek S2 bisa menentukan sisi miring pada setiap bentuk segitiga siku-siku serta dapat memahami rumus Pythagoras. Subjek 3 melakukan kesalahan konseptual mirip dengan subjek 1yaitu ketika mentransformasi soal ke dalam bentuk gambar (segitiga siku-siku). Subjek melakukan kesalahan konseptual yaitu subjek tidak memahami konsep arah mata angin sehingga subjek menggambar segitiga siku-siku tidak sesuai dengan yang dikehendaki soal. Subjek menggambar arah barat ke arah bawah dan menggambar arah selatan ke arah kanan. Wawancara yang dilakukan yaitu wawancara terkait arah mata angin sehingga subjek 2 dapat menggambar segitiga siku-siku sesuai dengan yang dimaksud soal. 
Pada penelitian sebelumya, Widyantari (2016) menyatakan kesalahan konseptual yaitu siswa melakukan kesalahan dalam menggunakan tanda sama dengan, siswa tidak menemukan rumus. Satiti (2014) menyatakan bahwa kesalahan konsep adalah kesalahan siswa dalam melakukan penafsiran istilah, konsep, dan prinsip.

\section{Kesalahan Prosedural}

Pada penelitian ini, semua subjek juga melakukan kesalahan prosedural. Bentuk kesalahan prosedural yang dilakukan semua subjek hampir sama sehingga pemberian tindakan wawancara untuk mengetahui kesalahannya lebih detail tidak jauh berbeda. Subjek 1, subjek 2 dan subjek 3 melakukan kesalahan prosedural pada saat menarik akar pada ruas kanan, tetapi di ruas kiri masih dalam bentuk kuadrat. Padahal seharusnya setelah ruas kiri dalam bentuk c maka ruas kanan baru ditarik akar pangkat dua. Dari kesalahan prosedural yang dilakukan oleh ketiga subjek, peneliti memberikan wawancara dengan tujuan yang sama. Pada penelitian sebelumnya terkait kesalahan prosedural, Widyantari (2016) menyatakan bahwa kesalahan prosedural pada siswa terjadi pada saat siswa menjawab soal tidak sesuai dengan langkah-langkahnya. Hiebert lefevre (1986) menyatakan bahwa kesalahan prosedural adalah kesalahan dalam menyusun tahapan-tahapan yang hierarkis sistematis untuk menjawab permasalahan.

\section{Kesalahan Komputasional}

Penghitungan merupakan keterampilan mendasar dalam ilmu matematika sehingga matematika pernah disebut ilmu berhitung. Pontoh (2013) menyatakan bahwa kesalahan yang sering dilakukan siswa dalam menyelesaikan soal cerita yaitu kesalahan dalam memahami soal, menghitung dan, menginterpretasikan jawaban model matematika.

Pada penelitian ini subjek 1 melakukan kesalahan komputasi pada saat penarikan akar dan menentukan selisih dua bilangan. Subjek melakukan kesalahan dalam menentukan penarikan akar kuadrat yaitu $\sqrt{1369}=39$, padahal yang benar adalah 37, karena subjek sudah salah dalam penarikan akar maka dalam menentukan selisihpun salah sehingga hasil akhir salah. Pada subjek 2 kesalahan komputasi terjadi ketika subjek melakukan penarikan akar. Ternyata subjek 2 dalam penarikan akar kuadrat tanpa dengan cara yang sebenarnya, tetapi dengan cara mengira-mengira. Sehingga perkiraan subjek 2 salah dan peneliti memberikan cara untuk menentukan akar kuadrat yang benar. Setelah mengetahui kesalahannya, subjek 2 mengubah jawaban dengan lebih hati-hati sehingga diperoleh jawaban yang benar. Pada kesalahan komputasi banyak siswa melakukan karena kurang hati-hati dalam penghitungan dan karena memang subjek tidak mengerti cara menentukannya. Pada subjek 3 melakukan kesalahan komputasi (penghitungan) terkait hasil pengurangan yaitu ketika menentukan selisih jarak tempuh, subjek melakukan kesalahan penghitungan karena subjek ceroboh dalam menghitung. Setelah mengetahui kesalahannya subjek 3 mengerjakan ulang dengan lebih hati-hati sehingga diperoleh jawaban yang benar. Pada kesalahan komputasi banyak siswa melakukan karena kurang hati-hati (ceroboh) dalam penghitungan. Penelitian terkait kesalahan komputasi di jelaskan oleh Widyantari (2016) menyatakan bahwa kesalahan komputasi adalah kesalahan dalam menghitung ketika menyelesaikan suatu masalah. White (2010) menyatakan bahwa kemampuan dalam menghitung dibutuhkan dalam matematika.

\section{SIMPULAN}

Berdasarkan pembahasan hasil penelitian dapat disimpulkan bahwa kesalahan-kesalahan yang dilakukan siswa dalam menyelesaikan soal cerita sebagai berikut. Pertama, kesalahan konseptual yang dilakukan berupa (a) subjek salah dalam menggambar segitiga yang tepat (b) kesalahan dalam menentukan sisi miring pada segitiga siku-siku padahal ini memengaruhi penyelesaian masalah dan hasil akhirnya. Kedua, kesalahan prosedural yaitu kesalahan yang dilakukan berupa saat menarik akar pada ruas kanan, tetapi di ruas kiri masih dalam bentuk kuadrat. Padahal seharusnya setelah ruas kiri dalam bentuk c maka ruas kanan baru ditarik akar pangkat dua. Ketiga, kesalahan komputasi yaitu kesalahan yang dilakukan berupa (a) siswa melakukan kesalahan dalam menentukan hasil akar pangkat dua (b) siswa melakukan kesalahan dalam menentukan selisih.

Penelitian ini hanya terbatas pada kelas VIII SMPN 2 Tiris Probolinggo. Oleh karena itu, tidak dapat diambil generalisasi kesimpulan. Agar dapat diambil kesimpulan yang lebih mendalam, perlu dilakukan penelitian secara kuantitatif dimana melibatkan siswa dengan kemampuan menyelesaikan masalah yang lebih beragam dan lebih banyak. Selain itu, langkah-langkah perbaikan pembelajaran perlu dilakukan untuk mengatasi kesalahan siswa dalam menyelesaikan soal cerita. Langkah-langkah perbaikan tersebut perlu memanfaatkan cara berpikir siswa yang lebih hati-hati, penguasaan konsep yang kuat serta penanaman prosedur yang tepat dalam menyelesaikan soal atau masalah.

\section{DAFTAR RUJUKAN}

Boaler, J. (1993). The Role of Contexts in the Mathematics Classroom: Do They Make Mathematics More "Real"? For the Learning of Mathematics, 13(2), 12-17. Diambil dari http://www.jstor.org/stable/40248079

Brown, J., \& Skow, K. (2016). Identifying Error Patterns. In Mathematics: Identifying and Addressing Student Errors (hal. 1620). http://doi.org/10.1002/ejoc.201200111

Chapman, O. (2006). Classroom practices for context of mathematics word problems. Educational Studies in Mathematics, 62(2), 211-230. http://doi.org/10.1007/s10649-006-7834-1 
Hiebert, J. \& Lefevre, P. (1986). Conceptual and Prosedural Knowledge in Mathematics: An Introductory Analysis. Hillsdale: Lawrence Erlbaum Associates.

Jonassen, D. H. (2003). Designing Research-Based Instruction for Story Problems. Educational Psychology Review, 15(3), 267-296. http://doi.org/10.1023/A:1024648217919

Jupri, A., \& Drijvers, P. (2016). Student Difficulties in Mathematizing Word Problems in Algebra. Eurasia Journal of Mathematics, Science \& Technology Education, 12(9), 2481-2502. http://doi.org/10.12973/eurasia.2016.1299a

Legutko, M. (2008). An Analysis of Students'Mathematical Errors in the Teaching-Research Process. Handbook for Mathematics Teaching: Teacher Experiment. A Tool for Research, 141-152.

Malau, L. (1996). Analisis Kesalahan Jawaban Siswa Kelas 1 SMU Kampus Nowmense Pematang Siantar Dalam Menyelesaikan Soal-Soal Terapan Siswa Persamaan Linear 2 Variabel. Tesis tidak diterbitkan. Universitas Negeri Malang, Malang.

Pontoh, S. (2013). Deskripsi Kesalahan Siswa Dalam Menerjemahkan Soal Cerita Ke Dalam Model Matematika dan Penyelesaiannya pada Pokok Bahasan SPLDV. Tesis tidak diterbitkan. Universitas Negeri Gorontalo, Gorontalo.

Rachmat, B. (2005). Analisis Kesalahan Siswa Dalam Menyelesaikan soal-soal Lingkaran. Tesis tidak diterbitkan. Universitas Negeri Surabaya, Surabaya.

Roselizawati., Sarwadi., \& Shahrill, M. (2014). Understanding Students' Mathematical Error and Misconceptions: The Case of Year 11 Repeating Students. Mathematics Education Trends and Research, doi: 10.5899/2014/metr-00051

Satiti, 2014. Analisis Kesalahan Siswa dalam Menentukan Akar-Akar Persamaan Kuadrat Melalui Tahapan Kastolan. FKIPUnviversitas Kristen Satya Wacana.

Scheiter, K., Gerjets, P., \& Schuh, J. (2010). The Acquisition of Problem-Solving Skills in Mathematics: How Animations can Aid Understanding of Structural Problem Features and Solution Procedures. Instructional Science, 38(5), $487-502$. http://doi.org/10.1007/s11251-009-9114-9

Sunardi. 1995. Analisis Kesalahan Mahasiswa dalam Menyelesaikan Soal Geometri Analitika Ruang Berdasarkan Taksonomi SOLO. IKIP-Malang

White, A. L. (2010). Numeracy, Literacy and Newman's Error Analysis. Journal of Science and Mathematics Education in Southeast Asia, 33(2), 129-148.

Widyantari. (2016). Analisis Kesalahan Siswa Berdasarkan Tahapan Kastolan Dalam Menyelesaikan Soal Cerita Matematika Materi Lingkaran Kelas VIII SMP Negeri Salatiga. Tesis tidak diterbitkan. FKIP Universitas Kristen Satya Wacana Salatiga, Salatiga. 